\section{Primocane-fruiting Blackberries: Potential for Extending Harvest Season and Production Regions}

\author{
Bernadine C. Strik ${ }^{1,3}$ and Ellen Thompson ${ }^{2}$ \\ Department of Horticulture, Oregon State University, 4017 ALS, Corvallis, \\ OR 97331-7304
}

Additional index words. Rubus sp., production systems, erect blackberry, primocane-fruiting blackberry, chilling, summer pruning, tipping

\begin{abstract}
Primocane-fruiting blackberries produce fruit on current-season canes (primocanes) and second-season canes (floricanes), if desired. Primocane-fruiting blackberries are likely adapted to a diverse range of climates, particularly because cold hardiness is not an issue when plants are grown for a primocane crop only. The floricane crop of 'Prime-Jan' ${ }^{\circledR}$ and 'Prime-Jim' ${ }^{\circledR}$ is from 3 June to 6 July in Arkansas and $30 \mathrm{June}$ to 22 Aug. in Oregon, thus overlapping with other fresh market blackberries. However, although the primocane crop overlaps with the semierect cultivar Chester Thornless, the fruiting season of the primocane-fruiting types is longer. Harvest on primocanes began 17 July and mid-August in Arkansas and Oregon, respectively. The primocanes of 'Prime-Jan' and 'Prime-Jim' tend to branch naturally, producing a couple of branches near the base. However, soft-tipping primocanes at $1 \mathrm{~m}$ early in the season increased branch and flower number, resulting in a threefold yield increase compared with untipped canes. Yield and berry size in Oregon has been from 1.8 to $5.2 \mathrm{t} \cdot \mathrm{ha}^{-1}$, depending on primocane management treatment, and 5.2 to $7.4 \mathrm{~g}$, respectively. However, yield would have been much higher if all fruit could have been harvested as would be possible under protected culture. Our research to date indicates that primocane-fruiting blackberry can be easily manipulated to adjust harvest time. Remowing primocanes to create a delayed flush of growth will delay harvest. Rowcovers or tunnels that increase temperature will advance primocane growth and harvest. Soft-tipping height and frequency can affect cane architecture and season. Management techniques along with new genotypes of primocane-fruiting blackberry will have a great impact on blackberry production worldwide.
\end{abstract}

The first commercial primocane-fruiting blackberry cultivars (Rubus L. subgenus Rubus), Prime-Jan ${ }^{\circledR}$ and Prime-Jim ${ }^{\circledR}$ (Univ. Arkansas, Fayetteville), were released in 2004 (Clark et al., 2005). This type of blackberry fruits on current-season canes (primocanes) and second-season canes (floricanes), if desired. All other types of blackberry fruit only on the floricane. Primocane-fruiting blackberries, like primocane-fruiting raspberries (Rubus idaeus L.), are likely adapted to a diverse range of climates, particularly because cold hardiness is not an issue when plants are grown for a primocane crop only. Although primocane-fruiting blackberries were not grown commercially in 2005, because they were too new, they were in trial in many regions worldwide (Strik et al., 2007). Drake and Clark (2003) suggested that these blackberries would be ideal for season

Received for publication 17 Nov. 2006. Accepted for publication 9 Dec. 2006.

This paper is part of the Breeding, Growing, and Marketing of Repeat-fruiting Small Fruit Cultivars for an Extended Season Workshop from ASHS-2006, New Orleans, LA.

${ }^{1}$ Professor and Extension Berry Crops Specialist.

${ }^{2}$ M.S. graduate student.

${ }^{3}$ To whom reprint requests should be addressed; e-mail strikb@hort.oregonstate.edu extension, but protected culture may be necessary in some regions and production systems needed to be developed.

\section{Flowering and Fruiting Morphology}

'Prime-Jan' and 'Prime-Jim' bloom on the floricanes beginning in early (Strik et al., 2008) to late April (Clark et al., 2005). The time from anthesis to black fruit is similar for both cultivars, averaging $57 \mathrm{~d}$ (Thompson et al., 2007). Fruit harvest ranged from 3 June to 6 July in Arkansas (Clark et al., 2005) and 30 June to 22 Aug. in Oregon (Strik et al., 2007). Reported yields range from 1.6 to 5.9 $\mathrm{t} \cdot \mathrm{ha}^{-1}$ in Arkansas (Clark et al., 2005) and 4.0 to $6.1 \mathrm{t} \cdot \mathrm{ha}^{-1}$ in Oregon (Strik et al., 2008). Berry size on floricanes ranged from 3.7 to 6.4 $\mathrm{g}$ in Arkansas (Clark et al., 2005) and 4.0 to $4.6 \mathrm{~g}$ in Oregon (Strik et al., 2008). Doublecropping (floricane + primocane crop) did not reduce the yield of the primocane crop (Drake and Clark, 2003; Strik et al., 2008).

In temperate climates, like Oregon, it is unlikely that primocane-fruiting blackberry will be double-cropped for commercial production. Harvest on the floricane crop is at the same time as other blackberry types such as the fresh market trailing blackberry cultivars Siskiyou and Obsidian and the erect cultivar Navaho considered to have much better fruit quality. Also, the yield of the floricane crop in 'Prime-Jan' and 'Prime-Jim' is not as high as that typically found in other erect blackberry and trailing blackberry cultivars. However, although the primocane crop overlaps with the semierect cultivar Chester Thornless, the fruiting season of the primocane-fruiting types is longer.

Date of first bloom on primocanes ranged from 16 June in Arkansas (Clark et al., 2005) to 14 to 22 July, depending on primocane management treatment, in Oregon (Strik et al., 2008). 'Prime-Jim' and 'Prime-Jan' averaged 46 and $52 \mathrm{~d}$ from anthesis to shiny black fruit, respectively (Thompson et al., 2007, 2008). Fruit harvest on primocanes began on 17 July in Arkansas and continued until frost, although fruit numbers were greatly reduced during higher temperatures in August (Clark et al., 2005). Stanton et al. (2007) showed that pollen germination, stigma receptivity, and pistil density were reduced at temperatures greater than $29^{\circ} \mathrm{C}$. Fruit harvest on primocanes began in midAugust in Oregon, depending on primocane management, and would have continued well into November had it not been for frost (Strik et al., 2008). Yield ranged from 0.2 to 3.0 $\mathrm{t} \cdot \mathrm{ha} \mathrm{a}^{-1}$ and berry size from 2.0 to $3.7 \mathrm{~g}$ in Arkansas (Clark et al., 2005). Yield and berry size in Oregon, in replicated plantings, has been from 1.8 to $5.2 \mathrm{t} \cdot \mathrm{ha}^{-1}$, depending on primocane management treatment, and 5.2 to 7.4 g, respectively (Strik et al., 2008). However, the yield potential in Oregon is higher if plants are protected from rain and all fruit can be harvested as is possible in a tunnel (Thompson, 2007).

\section{Primocane Management}

The effects of "soft-tipping" (removal of 2 to $5 \mathrm{~cm}$ ) primocane-fruiting blackberry primocanes on yield and berry size depended on when the tipping was done (Drake and Clark, 2003). "Soft tipping" late, when inflorescences appeared or later, reduced primocane yield and berry weight compared with untipped canes (Drake and Clark, 2003); we have had similar results in Oregon (Thompson and Strik, unpublished data).

The primocanes of 'Prime-Jan' and 'Prime-Jim' tend to branch naturally, producing a couple of branches near the base (Thompson et al., 2007, 2008). Primocanes that are not summer-pruned can reach over 2 $\mathrm{m}$ in height in Oregon. However, Strik et al. (2008) found that primocanes soft-tipped to 1 $\mathrm{m}$ (done in June) produced threefold the yield of untipped canes. This higher production is a result of a higher number of branches per cane, five on average, and threefold the flower number on soft-tipped canes (Thompson et al., 2007, 2008).

In our experience, a commercial primocane crop is not possible in the planting year when tissue-cultured plants are established $(0.6 \mathrm{~m}$ in the row). However, commercial crops should be expected the year after planting. A simple, two-wire trellis is recommended 
to prevent the vigorous canes from bending over and to prevent wind breakage.

\section{Off-season Production}

In primocane-fruiting raspberry, fruiting season can be modified by advancing or delaying primocane growth using rowcovers. Primocane-fruiting raspberries can also be manipulated to produce fruit at most times of the year in tunnels to target high-priced niche markets (Pritts et al., 1992). The possibilities for manipulating primocane-fruiting blackberries for off-season production seem equally promising. Strik et al. (2008) were able to advance bloom $14 \mathrm{~d}$ using rowcovers placed over the blackberry row before primocane emergence. Primocanes grew faster than those without rowcover and thus bloomed earlier. Flower bud initiation in primocane-fruiting blackberry may be dayneutral and dependent on primocane age as it is in primocane-fruiting raspberry. Primocane-fruiting blackberries growing from root cuttings initiated flower buds after a short period of growth after $\approx 20$ nodes developed; the terminal flower opened $\approx 35$ $\mathrm{d}$ after floral initiation (Lopez-Medina et al., 1999).

The chilling requirement of the floricane of 'Prime-Jim' seemed to range from 100 to $300 \mathrm{~h}$; however, the researchers also felt it may not have a chilling requirement because budbreak was variable (Carter et al., 2006). Chilling of root cuttings of primocane-fruiting blackberry genotypes enhanced primocane growth and flowering (Lopez-Medina and Moore, 1999). Our preliminary work indicates primocane growth and flowering from the crown may respond to chilling in 'Prime-Jan' (Thompson, 2007).

Our research to date indicates that primocane-fruiting blackberry can be easily manipulated to adjust harvest time. Remowing primocanes to create a delayed flush of growth will delay harvest. Rowcovers or tunnels that increase temperature will advance primocane growth and harvest. Soft-tipping of canes is necessary to manage primocane growth and to increase yield; however, tipping height can affect cane architecture and season. In addition, double-tipping, where primocane branches are soft-tipped also, shows great promise for increasing production (Thompson and Strik, 2007).

In summary, although primocane-fruiting blackberries are relatively new, research on production systems and variation in genotypes that are being used in breeding make us very optimistic that this type of blackberry will have a tremendous impact on the fresh market industry worldwide. New genotypes of primocane-fruiting blackberry that offer a high number of branches per primocane, short compact growth habit, and thornlessness will further advance the production of this type of blackberry (J. Clark, personal communication). Primocane-fruiting blackberries appear to be easily manipulated and thus offer great potential for extending the fresh market production season for blackberries.

\section{Literature Cited}

Carter, P.M., J.R. Clark, C. Drake Particka, and D. Yazzetti Crowne. 2006. Chilling response of Arkansas blackberry cultivars. J. Amer. Pom. Soc. 60:187-197.
Clark, J.R., J.N. Moore, J. Lopez-Medina, C. Finn, and P. Perkins-Veazie. 2005. 'Prime-Jan' ('APF-8') and 'Prime-Jim' ('APF-12') primocane-fruiting blackberries. HortScience 40:852-855.

Drake, C. and J.R. Clark. 2003. Effects of pruning and cropping on field-grown primocane-fruiting blackberries. HortScience 38:260-262.

Lopez-Medina, J. and J.N. Moore. 1999. Chilling enhances cane elongation and flowering in primocane-fruiting blackberries. HortScience $34: 638-640$.

Lopez-Medina, J., J.N. Moore, and K.-S. Kim. 1999. Flower bud initiation in primocane-fruiting blackberry germplasm. HortScience 34:132-136.

Pritts, M., E. Hanson, J. Fiola, and M.J. Kelly. 1992. Rowcovers accelerate fruiting and increase productivity in primocane-fruiting red raspberries. HortTechnology 2:46-51.

Stanton, M.A., J.C. Scheerens, R.C. Funt, and J.R. Clark. 2007. Floral competence of primocanefruiting blackberries Prime-Jan ${ }^{T M}$ and Prime$\mathrm{Jim}^{\text {TM }}$ grown at three temperature regimens. HortScience 42:1-6.

Strik, B.C., J.R. Clark, C.E. Finn, and M.P. Bañados. 2007. Worldwide production of blackberries, 1995 to 2005 and predictions for growth. HortTechnology 17:205-213.

Strik, B.C., J.R. Clark, C.E. Finn, and G. Buller. 2008. Management of primocane-fruiting blackberry to maximize yield and extend the fruiting season. Acta Hort. 777:423-428.

Thompson, E. 2007. Primocane-fruiting blackberries: the effect of summer-pruning, tipping, and chilling on primocane morphology, fruiting season, and yield. M.S. thesis, Dept. of Horticulture, Oregon State University, Corvallis.

Thompson, E., B.C. Strik, J.R. Clark, and C.E. Finn. 2007. Flowering and fruiting patterns of primocane-fruiting blackberries. HortScience 42:1174-1176.

Thompson, E., B.C. Strik, J.R. Clark, and C.E. Finn. 2008. Flowering and fruiting morphology of primocane-fruiting blackberries. Acta Hort. 777:281-288. 